1st International Conference - Global Ethics - Key of Sustainability (GEKoS) | May 15th, 2020 | Bucharest, Romania

\title{
Ethics and Sustainability in Small and Medium-Sized Enterprises Public Policies
}

\author{
Amalia-Elena ION \\ https://doi.org/10.18662/lumproc/gekos2020/09
}

How to cite: Ion, A.E. (2020). Ethics and Sustainability in Small and Medium-Sized Enterprises Public Policies. In A. Grigorescu \& V. Radu (vol. ed.), Lumen Proceedings: Vol. 11. 1st International Conference Global Ethics - Key of Sustainability (GEKoS) (pp. 74-85). Iasi, Romania: LUMEN Publishing House. https://doi.org/10.18662/lumproc/gekos2020/09 


\title{
Ethics and Sustainability in Small and Medium- Sized Enterprises Public Policies
}

\author{
Amalia-Elena ION 1
}

Abstract

In an age of important scientific and technological breakthroughs, among people that constantly search further, it is quite a challenge to stop in place and assess the situation from a sustainable dimension; more so, even harder to perceive at organizational and functional level a company and its actions based on ethical principles. The origins of etbics are still unclear, and sustainability is a globally promoted concept, mostly for its rhetorical value. Within the global economy, the ethical and sustainable decision-making process of businesses is not often linear, but it presents more or less the same manageable pattern, especially when the unit of analysis is represented by multinational companies. There is, though, a different guiding path for the small and mediumsized companies, and it all starts with the SME public policy. By making an analysis of SME public policy of the ASEAN countries, and by introducing the elements of business ethics and corporate social responsibility at the level of small economic entities, the research managed to create a backbone of a narrative of frameworks and approaches within the South-East AsianSME public policy. The research question of the paper simply manages to direct towards finding different perspectives on SME public policy and cases of ethical and sustainable decisions, based on secondary data, using a qualitative approach. The study resumes the knowledge on ethical and sustainable practices and guidance in the Asian SME sector, and adds to the current database a straightforward answer to the question: Are ASEAN SMEs ethical and socially responsible?

Keywords: ASEAN countries; ethical public policy; SME sustainability; ethics and sustainability.

\footnotetext{
${ }^{1}$ University of Valahia, Targoviste, Romania, amalia.ion@live.com.

(c) The Authors, LUMEN Conference Center \& LUMEN Proceedings.

Selection and peer-review under responsibility of the Organizing Committee of the conference
} 


\section{Introduction}

The business ethics field is mostly concentrated on the study of large enterprises, as the norm has always been to recognize the appropriate measures that the latter have been able to institute, creating, thereby, a framework to which other enterprises could abide. Most scholars grounded their research in case studies regarding ethical and sustainable operations and principles within the family of multinational companies. When observing the same variables from the perspective of globalization and politico-economic structures, there are more lacunas on the subject. For instance, information regarding ethical practices within economic entities, both SMEs and large companies, from different states across the world is subjected to the potential of the legislation, which, for different reasons not transposed here, could not be clearly interpreted in real-world business examples.

Therefore, not only there is a lack of uniformity on ethics and sustainability at a global level, but there is a considerable gap and unevenness within the international public policies for SMEs comprising of ethical and sustainable principles. This paper has managed to undertake the furthering on the subject, with the documenting of the SME public policies across the Asian continent regarding the ethical practices and the CSR instituted frameworks. The research will provide with building on the gap both in terms of international representation and content. Moreover, knowing that there is a clear differentiation between ethics in companies of various sizes, it is important to start from the presumption that SMEs are vulnerable and uncertain in terms of evolution and activity. There is a focus on the fact that ethical principles applicable to large enterprises would not be suited or available to the smaller counterparts.

In essence, this research offers a perspective on the SME public policy regarding the ethical and sustainable practices of the ASEAN countries, by considering the clear and unbounded differentiation in terms of geographical and economic positioning.

\section{Problem Statement}

The legislation on ethics and sustainability for enterprises has grown exponentially and globally in the last decade, especially due to the everincreasing concerns regarding environmental and ecological abilities of various entities to make a plausible difference in effects and results. The cultural heritage of each country of the world creates a basis for the legislation on ethics and sustainability. For instance, the Arab countries are defined by their religion, and research [1] introduced the phenomenon of 
Eco-Islam within the organizational culture as a complementary mechanism for ethics and environmental sustainability, especially considering the cultural context in which SMEs in the Middle East countries operate. On the other hand, countries from Africa are facing challenges regarding the financing failures of SMEs with implications from an ethical perspective [10], as the weak ethical perception of the new small enterprises represents a decisive element in the approval of foreign trade credit. Turning back to the East, Japan is exemplary of a high-income, innovative, and technologized economy; but here is also the case of profound cultural heritage and tradition that interferes in the business sector, which, for the SMEs particularly, fundamentally influences the ethical and sustainable decisions [13]. The Chinese counterparts, on the other hand, even though they are highly concerned with everything that pertains to ethics and sustainability, offer a lesser example in terms of engagement [30], mostly driven by insufficient financial resources, lack of external support and awareness on behalf of the Chinese SMEs. Moving towards the Tasman Sea, the governments of Australia and New Zealand have adopted some policies on ethics and sustainability for SMEs [6], although there have been not too many cases of initiatives and directions for small enterprises to engage in ethical and sustainable practices, especially in New Zealand, as reported in a survey[18] no sustainable practices but social and ethical responsibility towards the community and employees. In the Western world, studies[3] showed that there is a connection between the managerial styles and leadership strategies within Canadian SMEs, and the commitment of the latter towards ethical and sustainable practices. The US small and mediumsized enterprises are regulated through the Small Business Act, and includes information on the facilitation of technology transfers, involvement and aid of minority entrepreneurs, shared production facilities, access to online data, reduction in the use of paper [12]. The European Union is probably the main focus of the research on ethics and sustainability in the SME sector, with papers referring to subjects such as the implementation of responsible research and innovation (RRI) within the SME public policy for the development of ethical and sustainable activities and organizational frameworks [2], andsetting standards that promote innovation and effective corporate reporting, as well as creating the perfect hub for experimentation [4] in an ethical, globalized world. Finnish SMEs have been the centre spot for a content analysis research on how circular business models could improve the sustainability of the former [8], while small Italian enterprises follow the entrepreneur's values and orientation in their diffusion of CSR practices [9], and Spanish SMEs find themselves in a nascent state of CSR and government initiatives [22]. 
Generally, ethics and sustainability policies and practices of the SME industry were debated from all sorts of perspectives, including the validation for CSR practices and ethical behaviour of SMEs compared to multinationals [27], the means by which an SME could implement an ethical infrastructure [11] based on cultural, linguistic and institutional environment [23], on technology and computer-integrated manufacturing [5], or simply on the certification of sustainable entrepreneurship [7].From defining the role CSR has in the development of SMEs [14], and perfecting the tools for sustainable management [15], to braking the grounds in sustainable innovation [16] and eco-innovation in SMEs [17], the search for ethical and sustainable practices in SMEs has always been linked to entrepreneurship [19],[20],[24]. Furthermore, sustainability in SMEs [25], [26] is fostered through and encouraged by the development of viable public policies [29], with the ultimate aim of creating value [28] based on ethical and sustainable decisions.

Nevertheless, there are still numerous questions to answer, especially if, in the end, an economic entity such an SME can prove to be able to proactively engage in ethical and sustainable practices based on the influence of the public policy in the sector. This research has looked into the directions governance and public policy has instituted towards SMEs, internationally, to create an outline of the possibilities and opportunities each country or region under study offers to small enterprises to perform under ethical and sustainable principles.

\section{Research Questions/Aims of the research}

The purpose of the research remains that of gathering and structuring the information on ethical and sustainable principles within the SME public policy at a continental level. The paper will review the public policy on SMEs from the dimension of ethics, and it will cover geographical ground on countries that are less approached by the majority of researchers. The study includes the ASEAN countries. The reason for choosing to explore the information that the SME public policy contains on ethics in the above-mentioned countries was, naturally, inspired by the need to engage in operational work that adds to the knowledge on the subject without being redundant.

\section{Research Methods}

The research has utilized a qualitative approach for the study, by analysing and reviewing official documentation consisting of public policies for 
SMEs. The main elements that have been sought for have been ethics and ethical practices, as well as any CSR and sustainabilityreferences. The study has followed the policy development phases, focusing the research on the content evaluation stage, where the problem has been identified, the policy analysed and the strategy and policy developed. All in all, the study has been straightforward, all the necessary materials have been sourced online, and the process of obtaining the necessary data for the research was performed without any hindering, with the limitation of the founded materials, collected and published by the OECD and ERIA.

In order to avoid redundancy, the countries selected for the public policy analysis have been the following: Brunei Darussalam, Cambodia, Indonesia, Lao PDR, Malaysia, Myanmar, The Philippines, Singapore, Thailand, Viet Nam.

\section{Findings}

\subsection{ASEAN countries}

The research has analysed the content of the SME Policy Index: ASEAN countries 2018 [21]. The importance of this group of countries resides in their abundance of fundamental resources, such as oil, gas, coal, minerals, metals, precious stones, timber, palm oil, rice, cocoa, coffee. They have also growing economies, as the technological advancements have put the ASEAN countries in the global manufacturing and trade scene for electronics, automobiles and textiles. The findings on ethical and sustainable SME policies for this group have been summarized below.

Brunei Darussalam is the smallest ASEAN country, but has the second highest income of the ASEAN countries, with $60 \%$ of GDP coming from crude oil and natural gas production. The MSME policy is relatively new, nevertheless, was created to build a dynamic and sustainable economy.The last 6 years have witnessed the creation of new bodies for SME policy and programmes development (FAST, DARe, MEMI, etc.). The SME policy does not focus on ethical and sustainable practices and principles, although there are some measures regarding pollution control, solid waste management and air quality control.

Cambodia has fewer natural resources than its neighbours, and is focused on garment production due to low wages (ethically debatable) and tax incentives. The bodies formulating SME policy are the SCSME and the MIH (Ministry of Industry and Handicraft), which presented the Industrial Development Policy (2015-2025) for SME modernization and development. Cambodian SMEs rely on laboratories in neighbouring countries for quality 
standards approval. Moreover, the country did not implement any regulatory incentives for greening the SME industry.

Indonesia has considerably more green SMEs than the previous countries, as it is also the largest ASEAN member, and the major global producer of rubber, palm oil and grains. A stringent problem in this country remains corruption, although there are bodies of control such as the Corruption Eradication Commission (KPK). Within the public policy for SMEs there are encountered a number of subjects such as providing support to ethnic populations (pribumi), providing some financial and tax exemptions to small enterprises, making mandatory for large enterprises to establish partnerships with SMEs in certain sectors of the economy, issuing legislative procedures (Circular Letter No. 2/2016 regarding Enhancement of Efficiency and Transparency in Handling Bankruptcy and PKPU Cases in Court), providing training on safety certification programmes for SMEs, supporting green growth (Green Industry Development Plan), creating green industry standards, and supporting $\mathrm{R} \& \mathrm{D}$ in green technology, renewable energy systems, and technology transfer. Moreover, Indonesia is actively expanding the concept of inclusive entrepreneurship to women and people with disabilities, as well as the youth.

Lao PDR is a predominantly rural economy, with $71 \%$ of employment in agriculture. The Department of SME Promotion is currently developing environmental SME policies through the Environmental Protection Law, setting standards for natural resources' use and disposal, and the National Renewable Energy Strategy, establishing the targets for renewable forms of energy. There are no incentives for green SMEs, but there are a number of European projects, including SWITCH-Asia, that support eco-labels and cleaner production.

Malaysia is one of the richest ASEAN countries with high scores on poverty reduction and human development. Its reform priorities include joining the high-income countries this year. Malaysia does have numerous policies that pertain to the subject of ethics and sustainability, including the creation of an equitable society, the improvement of well-being (Malaysian Well-being Index - MWI) and life standards, the pursuit of green growth for sustainability reasons. In terms of environmental policies for SMEs, Malaysia has implemented the Green Technology Plan and the National Green Technology Policy. Moreover, the MyHIJAU SME \& Entrepreneur Development Programme helps small enterprises to adopt green practices, while the government offers incentives to green SMEs.

Myanmar is a predominantly rural economy, and the topic of SMEs is not the main concern. There is, though, a regulatory body responsible for this sector - the SME Development Department. There are not too many 
quality standards in place, and the SMEs do not receive incentives to improve the know-how and the quality standards. Moreover, Myanmar does not have sustainability at the core of its SME policies.

The Philippines is the second largest ASEAN country, with high rates of literacy ( $96,4 \%$ of the country's adult population). Its economy is also growing at high rates, and the private sector is quite robust, benefiting from a large market and stable economic environment. The main legislation for MSMEs is the Republic Act 6977, or the Magna Carta for Small Enterprises, and the body responsible for SME legislation is the National Competitive Council. The Bureau of Product Standards (BPS) is responsible for the compliance of national quality standards to international ones. The SMEs' compliance to the quality standards is perfected through the form of trainings on a wide range of subjects: product packaging, labelling, food safety, etc. The Philippines have issued the MSMED Plan 2017-2022, the National Climate Change Action Plan, the Strategy Framework to Ensure Ecological Integrity, Clean and Healthy Environment; all the programmes and regulations have the purpose of prioritizing sustainability of SMEs.

Singapore operates on a completely different and superior level than all the other ASEAN countries. They have instituted strategies for international connections, skills development, digital capabilities, innovation and growth, with the final purpose of creating a sustainable environment. Within the Economic Development Board, there is an SME Committee that formulated the Master Plan for SME development. Based on the latter, more programmes have been developed since, for the innovation growth in SMEs, and the creation of a knowledge-based SME environment. EDC, SPRING and IE Singapore are the legislative bodies for SME policy, and they have issued quality standards in conformance with international levels, they have facilitated international trade and logistics performance, they have created dedicated action plans for the provision of services to SMEs in the effort for further development, they have supported the R\&D centres, and they have set environmental performance targets for SMEs in the form of sustainable certification of buildings, energy and water consumption and also recycling. Moreover, the government provides incentives to SMEs through the Energy Efficiency Fund for the latter to improve the environmental performance. Also, the SMEs Development Plan contains policies regarding the access to entrepreneurial education, and social and inclusive entrepreneurship programmes.

Thailand is the second largest economy in ASEAN, due to the FDI and export-oriented strategy for industrialization. The SME sector in Thailand is very productive, having a $78,5 \%$ share of employment, and the policy for SMEs is focused on continuously developing the economy, and 
diversifying the productive structure. The first SME policy in Thailand was the SME Promotion Act, formulated in 2000; since then, SMEs have been facilitated through public policy the access to different resources, including finance (Small Industry Credit Guarantee Corporation Act). The Thai Industrial Standards Institute is certifying the community products for international level quality. Moreover, the National Economic and Social Development Plan focuses on the green policies for SMEs, including environmentally friendly growth for sustainable development, green labelling, green industrial manufacturing, life-cycle assessment on products, and green procurement policies, among others.SMEs are also helped by the Bureau of Environmental Technology to adopt environmental management systems and green technology transfers.

Viet Namis a lower-middle income, predominantly rural country, with a dual economy, and, generally, 5-year policy plans. $98 \%$ of the businesses in this country are MSMEs, and they are all regulated through the SME law of 2017. Compared to all the other ASEAN countries, Viet Nam is nowhere near the legislative prospective of a growing economy. The quality standards are regulated through the STAMEQ, but certification of service quality, for instance, is provided by private entities. There is no transparent support for SMEs to meet international quality standards. Moreover, there are no specific policies for SMEs to become environmentally aware, and to practice sustainable principles, and there is no government agency that works exclusively with SMEs on this matter. At the same time, there are no incentives for SMEs that intend to achieve sustainability certificates or to simply institute sustainable practices.

\section{Conclusion}

The ASEAN countries are quite spread in terms of development and economic growth, but, when it comes to SME public policy the differentiation is not that profound, rather it can be observed across multiple time phases. All in all, the ethical and sustainable principles in the SME public policy are not the main concern for the majority of those countries. It is imperative for them to first develop and adjust the SME market to a point where the small enterprises can actually find themselves in situations where they request the existence of certain quality standards, of incentives for sustainable manufacturing and trading, or of support in the development of social and inclusive entrepreneurship.

The richer countries of Southeast Asia not only opened dedicated bureaus for SME public policy, but also issued regulations and programmes to develop and support this growing economic sector through green, 
sustainable and ethical initiatives. Nevertheless, there is a long way before ASEAN SME public policies start to focus on practices that pertain to the development of green directives. The 10 countries under study can be categorized based on their public policy on SMEs regarding sustainability, CSR practices and ethical principles as following: no or few SME policies for ethical and sustainable practices; growing SME policies for ethical and sustainable practices; and significant SME policiesfor ethical and sustainable practices. Within the first category, the study allocated Brunei Darussalam, Cambodia, Myanmar and Viet Nam. The second category comprises of Lao PDR, The Philippines and Malaysia. And the third category includes Indonesia, Singapore, and Thailand. The basis for differentiating the second and third category countries has been the range of ethical and sustainable practices and principles those countries have included in their SME policies. For instance, even though, Malaysia has instituted a considerable number of directives towards greening the SME sector, Thailand proved that the focus cannot be generally directed, rather spread across a wide range of fields of interests, such as industrial manufacturing, environmentally friendly growth, product life-cycle assessment, or even green procurement.

In conclusion, to answer the research question less vaguely, the SME public policy in Southeast Asian countries is not yet generally focused on principles that pertain to ethics and sustainability, but the promising outlook of SMEs in these countries through the rising global value chain investments is bringing a fresh perspective on how SME policy can be improved. The study can be furthered by developing questionnaires for each country, to actually understand, from an entrepreneurial perspective the ways in which SME policies can be alternated and perfected based on ethical and sustainable principles.

\section{References}

[1] Abdelzaher DM, Abdelzaher A. Beyond Environmental Regulations: Exploring the Potential of "Eco-Islam" in Boosting Environmental Ethics Within SMEs in Arab Markets. Journal of Business Ethics. 2015; 145(2): 357-371. Available from: https://link.springer.com/article/10.1007/s10551-015-2833-8.

[2] Auer A, Jarmai K. Implementing Responsible Research and Innovation Practices in SMEs: Insights into Drivers and Barriers from the Austrian Medical Device Sector. Sustainability. 2018; 10(1): 1-18. Available from: https://epub.wu.ac.at/5956/.

[3] Boiral O, Baron C, Gunnlaugson O. Environmental Leadership and Consciousness Development: A Case Study Among Canadian SMEs. Journal of 
Business Ethics. 2013; 123(3): 363-383. Available from: https://link.springer.com/article/10.1007\%2Fs10551-013-1845-5.

[4] Boutellis-Taft O. New Relevance of Accounting and Reporting: SMEs, Ethics and Sustainability. In: Kaili E, Psarrakis D, Hoinaru R. New Models of Financing and Financial Reporting for European SMEs. 1 ${ }^{\text {st }}$ Edition. Cham: Palgrave Macmillan; 2019, pp. 95-105/

[5] Burke S, Gaughran WF. Developing a framework for sustainability management in engineering SMEs. Robotics and Computer-Integrated Manufacturing. 2007; 23(6): 696-703. Available from: https://doi.org/10.1016/j.rcim.2007.02.001.

[6] Collins E, Dickie C, Weber P. A New Zealand and Australian overview of ethics and sustainability in SMEs. African Journal of Business Ethics. 2009; 4(2):48-55. Available from: https://doi.org/10.1007/978-90-481-9331-8 6 .

[7] Crals E, Vereeck L. The affordability of sustainable entrepreneurship certification for SMEs. International Journal of Sustainable Development \& World Ecology, 2005; 12(2): 173-183. Available from: https://www.researchgate.net/deref/http $\% 3 \mathrm{~A} \% 2 \mathrm{~F} \% 2 \mathrm{Fdx} \cdot d o i . o r g \% 2 \mathrm{~F} 10.1080$ \%2F13504500509469628.

[8] D'Amato D, Veijonaho S, Toppinen A. Towards sustainability? Forest-based circular bioeconomy business models in Finnish SMEs. Forest Policy and Economics; 2018 Available from: https://www.sciencedirect.com/science/article/pii/S1389934118302600.

[9] Del Baldo M. Corporate social responsibility and corporate governance in Italian SMEs: towards a 'territorial' model based on small 'champions' of CSR?. International Journal of Sustainable Society. 2010; 2(3): 215-247. Available from:

https://www.inderscienceonline.com/doi/abs/10.1504/IJSSoc.2010.034762.

[10] Fatoki OO. The Impact of Ethics on the Availability of Trade Credit to New Small and Medium Sized Enterprises (SMEs) in South Africa. Journal of Social Sciences. 2017; 30(1): 21-29. Available from: https://doi.org/10.1080/09718923.2012.11892979.

[11] Fernandez JL, Camacho J. Effective Elements to Establish and Ethical Infrastructure: An Exploratory Study of SMEs in the Madrid Region. Journal of Business Ethics. 2015; 138(1): 113-131. Available from: https://doi.org/10.1007/s10551-015-2607-3.

[12] Grigorescu A, Ion AE. A Content Analysis on the Small and Medium-Sized Enterprises in the United States of America. Tékhne. 2019; 17(1):39-52. Available from: https://content.sciendo.com/view/journals/tekhne/17/1/articlep39.xml?tab body=pdf-69320.

[13] Hasnah H, Ishak I, Sobei O. Ethics, Corporate Social Responsibility and The use of advisory services provided by SMEs: Lessons learnt from Japan. Asian Academy of Management Journal. 2015; 20(1):71-100. Available from: http://web.usm.my/aamj/20012015/Art\%204\%20new\%20(71-100).pdf. 
[14] Inyang BJ. Defining the Role Engagement of Small and Medium-Sized Enterprises (SMEs) in Corporate Social Responsibility (CSR). International Business Research. 2013; 6(5): 123-132. Available from: https://doi.org/10.5539/ibr.v6n5p123.

[15] Johnson MP, Schaltegger S. Two Decades of Sustainability Management Tools for SMEs: How Far Have We Come? Journal of Small Business Management [Internet]. 2015; 54(2):481-505. Available from: https://doi.org/10.1111/jsbm.12154.

[16] Klewitz J, Hansen EG. Sustainability-oriented innovation of SMEs: a systematic review. Journal of Cleaner Production. 2014; 65: 57-75. Available from: https://doi.org/10.1016/j.jclepro.2013.07.017.

[17] Klewitz J, Zeyen A, Hansen EG. Intermediaries driving eco-innovation in SMEs: a qualitative investigation. European Journal of Innovation Management [Internet]. 2012; 15(4): 442-467. Available from: https://doi.org/10.1108/14601061211272376.

[18] Lawrence S, Collins E, Pavlovich K, Arunachalam M. Sustainability practices of SMEs: The case of NZ. Journal of Business Strategy and the Environment [Internet]. 2006; 15(4):242-257. Available from: https://doi.org/10.1002/bse. 533 .

[19] Markman GD, Russo M, Lumpkin GT, Jennings PDD, Mair J. Entrepreneurship as a Platform for Pursuing Multiple Goals: A Special Issue on Sustainability, Ethics, and Entrepreneurship. Journal of Management Studies [Internet]. 2016; 53(5): 673-694. Available from: https://doi.org/10.1111/joms.12214.

[20] Nowduri S. Framework for Sustainability Entrepreneurship for Small and Medium Enterprises (SMEs) in an Emerging Economy. World Journal of Management [Internet]. 2012; 4(1): 51-66. Available from: http://modul.repo.mercubuanayogya.ac.id/modul/files/openjournal/JournalOfBusineess / 4.\%20Srinivas.pdf.

[21] OECD/ERIA. SME Policy Index: ASEAN 2018: Boosting Competitiveness and Inclusive Growth. Paris: OECD Publishing; Jakarta: Economic Research Institute for ASEAN and East Asia; 23 March 2018. 494. Report No.: 1. Available from: https://doi.org/10.1787/9789264305328-en.

[22] Rivera-Lirio JM, Muñoz-Torres MJ. Sustainable development in the Spanish region of Valencia and the social responsibility of SMEs. A multi-stakeholder vision on the role of public administrations. Journal of Environmental Planning and Management . 2010; 53(5): 573-590. Available from: https://doi.org/10.1080/09640561003694419.

[23] Schlierer HJ, Werner A, Signori S, Garriga E, von WeltzienHoivik H, Van Rossem A, Fassin Y. How Do European SME Owner-Managers Make Sense of "Stakeholder Management"? Insights from a Cross-National Study. Journal of Business Ethics. 2012; 109(1): 39-51. Available from: https://doi.org/10.1007/s10551-012-1378-3. 
[24] Spence M, Ben BoubakerGherib J, OndouaBiwolé V. Sustainable Entrepreneurship: Is Entrepreneurial will Enough? A North-South Comparison. Journal of Business Ethics. 2010; 99(3):335-367. Available from: https://doi.org/10.1007/s10551-010-0656-1.

[25] Stubblefield Loucks E, Martens ML, Cho CH. Engaging small- and medium-sized businesses in sustainability. Sustainability Accounting, Management and Policy Journal. 2010; 1(2):178-200. Available from: https://doi.org/10.1108/20408021011089239.

[26] Tewari R, Pathak TS. Sustainable CSR for Micro, Small and Medium Enterprises.Journal of Management \& Public Policy. 2014; 6(1): 34-44. Available from: https://www.researchgate.net/deref/http $\% 3 \mathrm{~A} \% 2 \mathrm{~F} \% 2 \mathrm{Fdx}$.doi.org $\% 2 \mathrm{~F} 10.2139$ \%2Fssrn.2600570.

[27] Tigu G, Popescu D, Ion R. Corporate Social Responsibility - an European Approach through the Tourism SME's Perspectives.Amfiteatru Economic Journal. 2016; Vol. 18 Special Issue 10: 742-756. Available from: http://hdl.handle.net/10419/169033.

[28] Vincenza Ciasullo M, Troisi O. Sustainable value creation in SMEs: a case study. The TQM Journal. 2013; 25(1): 44-61. Available from: https://doi.org/10.1108/17542731311286423.

[29] Walker H, Preuss L. Fostering sustainability through sourcing from small businesses: public sector perspectives. Journal of Cleaner Production. 2008; 16(15): 1600-1609. Available from: https://doi.org/10.1016/i.jclepro.2008.04.014.

[30] Yu J, Bell JNB. Building a sustainable business in China's Small and mediumsized enterprises (SMEs). Journal of Environmental Assessment Policy and Management.; 9(1):19-43. Available from: https://www.worldscientific.com/doi/abs/10.1142/S1464333207002718. 